Thời gian nằm viện điều trị của các bệnh nhân trung bình là 9,9 ngày (6-15 ngày), bệnh nhân nằm viện lâu hơn do tuổi cao, sức khỏe yếu, có bệnh lý phối hợp, khả năng phục hồi sau mố chậm hơn. Nhiều bệnh nhân phải điều trị nội khoa trước mổ, nâng cao thể trạng; trong và sau mổ phải theo dõi và phục hồi chức năng tích cực nên thời gian nằm viện của nhóm nghiên cứu dài hơn. So sánh thấy thời gian nằm viện trong nhóm nghiên cứu của chúng tôi tương tự với các tác giả $[5,6,7,8]$.

Trong nghiên cứu này ghi nhận 1 trường hợp nhiễm trùng nông sau mổ, chúng tôi thay đổi kháng sinh, nâng cao thể trạng, sau 2 tuần bệnh nhân ổn định, không có viêm rò; chúng tôi không ghi nhận có các tai biến của gây tê, gây mê, tắc mạch, viêm phổi, loét tỳ đè hay tử vong. Đây là một ưu thế của phương pháp điều trị, thời gian phẫu thuật khoảng 30 phút, bệnh nhân không có cảm giác đau, sau mổ được giảm đau tốt, tập vận động sớm tránh được các biến chứng do nằm lâu gây ra.

Kết quả nghiên cứu có $90,9 \%$ đạt tốt và rất tốt, $5,5 \%$ đạt khá và $3,6 \%$ đạt kém. Kết quả này cũng tương tự với các giả khác $[5,6,7,8]$ cho thây sự phù hợp của phương pháp đối với bệnh nhân trên 80 tuổi. Từ đó có thể đưa ra khuyến cáo, chỉ định phẫu thuật thay khớp háng bán phần không xi măng cho nhóm bệnh nhân trên 80 tuổi gãy cổ xương đùi.

\section{KẾT LUẦN}

Qua nghiên cứu 55 bệnh nhân trên 80 tuổi gãy cổ xương đùi được phẫu thuật thay khớp háng bán phần không xi măng tại Bệnh viện Hữu Nghị Việt Đức trong thời gian từ 1/2017 12/2019 với độ tuổi trung bình 86,5 (80 -102 tuổi) cho kết quả tốt và rất tốt $90,9 \%$, khá $5,5 \%$, kém 3,6\%. Không gặp các biến chứng gây tê, gây mê, tắc mạch, viêm phổi, loét tỳ đè hay tử vong. Phẫu thuật thay khớp háng bán phần không xi măng là một lựa chọn tốt cho bệnh nhân trên 80 tuổi bị gãy cổ xương đùi.

\section{TÀI LIỆ THAM KHẢO}

1. Ong B.C., Maurer S.G. Ahronoff G.B., Zuckerman J.D., Koval K.J. (2002), "Unipolar versus bipolar hemiarthroplasty: Funtional outcome after femoral neck fracture at a minimum of thirty-six months of follow-up", Jorthop trauma, 16(5), pp. 317-22, Mediline.

2. Anthony D., Barat Z. Marke; Joseph Watson; Imbriglia E. (1998), "Femoral neck fracture", Orthopaedic surgery, pp. 489-491.

3. R. P. Pitto, M. Koessler và J. W. Kuehle (1999). Comparison of fixation of the femoral component without cement and fixation with use of a bone-vacuum cementing technique for the prevention of fat embolism during total hip arthroplasty. A prospective, randomized clinical trial. J Bone Joint Surg Am, 81 (6), 831-843.

4. Nguyễn Tiến Bình, Nguyến Ngọc Liêm (1999), "Nhận xét kết quả 126 trường hợp thay khớp háng toàn phần và bán phần tại Bệnh viện TW Quân đội 108", Báo cáo khoa học đại hội ngoại khoa toàn quốc lần thứ 10", tr. 135-137.

5. Đinh Thế Hùng (2000), " Kết quả bước đầu phẩu thuật thay khớp háng bán phần trong điều trì gãy cổ xửong đùi ở ngươơi cao tuổi", Ngoại khoa, Y hoc Việt Nam số 3,4, tr. 33-37

6. Bùi Hoàng Bột (2013), "Đánh giá kết quả thay khớp háng bán phần điêu trị gãy cổ xương đùi ở người cao tuổi băng kỹ thuật ít xâm lẫn", Luận văn tôt nghiệp bác sỹ chuyên khoa II, Trường đại học y Hà Nôi

7. Nguyến Manh Khánh, Nguyễn Xuân Thùy (2016) ,"Kểt quả phẩu thuât thay khớp háng bán phần có xi măng trên bệnh nhân gãy cổ xương đùi có loãng xương". Tạp chí y học Việt Nam số 2 tháng 4/2016, Tâp 441. Tr. 216-219.

8. Vũ Văn Khoa, Nguyền Văn Nam (2019), "Đánh giá kết quả thay khớp háng bán phần chuồ dài điều trị gãy liên mấu chuyển xương đùi ở người cao tuối". Tạp chí y học Việt Nam số 1 tháng 8/2019, tập 481. Tr. 120-122.

\title{
XÁC ĐİNH ĐộT BIẾN GEN CYP21A2 TRÊN BÊ̂NH NHÂN TĂNG SẢN THƯợNG THÂ̂N BẨM SINH THIẾU 21-HYDROXYLASE THỂ KHÔNG CỔ ĐIỂN
}

\section{Trần Huy Thịnh ${ }^{1}$, Vũ Chí Dũng1,2, Trần Vân Khánh ${ }^{1}$}

\section{TÓM TẮT}

\author{
${ }^{1}$ Trường Đại học Y Hà Nội, \\ ²Bênh viện Nhi Trung ướng \\ Chịu trách nhiệm chính: Trần Vân Khánh \\ Email: tranvankhanh@hmu.edu.vn \\ Ngày nhận bài: 19.2.2021 \\ Ngày phản biên khoa hoc: 25.3.2021 \\ Ngày duyệt bài: 5.4 .2021
}

Tăng sản thượng thận bẩm sinh do thiếu hụt enzym 21- hydroxylase là bệnh di truyền lặn nhiếm sắc thể thường gây nên do đột biến gen CYP21A2. Bệnh được chia thành 3 thể bệnh lâm sàng chính là thể mất muối, thể nam hóa đớn thuân và thể không cổ điển. Ở thể không cổ điển, cortisol và aldosterone được sản xuất bởi vỏ thượng thận giúp ngăn ngừa được các biểu hiên lâm sàng cần phải điều trị bằng liệu pháp thay thế, tuy nhiên bệnh nhân vẫn chịu các rối loạn về nội tiết gây ra do nồng đồ androgen cao 
trong máu. Nghiên cứu được thực hiện với mục tiêu: Xác định đôt biến gen CYP21A2 trên các bênh nhân tăng sản thượng thận bẩm sinh thể không cổ điển. Phương pháp: 4 bệnh nhân TSTTBS thể không cổ điển được mô tả lâm sàng và phân tích phân tử xác định đột biến trên gene CYP21A2. Kết quả: 4 bệnh nhân có biểu hiện lâm sàng của thể cổ điển đều có đột biến gen CYP21A2. 75\% bệnh nhân (3 trong 4) đều là nam và có kiểu gen p.V281L/p.L307FfsX6. Bệnh nhân còn lại là nữ, có kiểu gen: p.P30L + p.P459_L464dup/ p.P459_L464dup, đây là một đột biến mới chưa được công bố

Tư khóa: TSTTBS, đột biến điểm gen CYP21A2, giải trình tự gen

\section{SUMMARY \\ MUTATION IDENTIFICATION OF CYP21A2 FOR PATIENTS WITH NON-CLASSICAL FORM OF CONGENITAL ADRENAL HYPERPLASIA DUE TO 21-HYDROXYLASE DEFICIENCY}

Congenital adrenal hyperplasia $(\mathrm{CAH})$ due to 21hydroxylase deficiency (21-OHD) is autosomal recessive disorder caused by mutations in $C Y P 21 A 2$. The clinical severity is classified into classical form including the salt-wasting and the simple virilizing form, and the non-classic (NC) form. Individuals with the non-classic form of 21-OHD $\mathrm{CAH}$ present postnatally with signs of hyperandrogenism; females with the non-classic form are not virilized at birth. Objective: to identify mutations of CYP21A2 in patients with non-classic form of $\mathrm{CAH}$ due to 21-OHD. Patiens and Method: the clinical phenotype was described and the mutation analysis of CYP21A2 was performed for four cases with non-classic form of $\mathrm{CAH}$. Results: the mutations of CYP21A2 were identified in all four studied cases. Three of four patients $(75 \%)$ are males and have genotype of p.V281L/p.L307FfsX6. One case is female and has genotype of p.P30L + p.P459 L464dup/ p.P459 L464dup. The variant of p.P459_L464dup was not reported in the database of $C Y P 21 \bar{A} 2$ mutations

\section{I. ĐẶT VẤN ĐỀ}

Tăng sản thượng thận bẩm sinh (TSTTBS) là một nhóm các bệnh di truyền lặn nhiễm sắc thể thường do thiếu một trong các enzym cần thiết cho quá trình tổng hợp cortisol từ cholesterol của vỏ thượng thận. Khoảng 95\% các trường hợp là do thiểu hụt 21 -hydroxylase $(21-\mathrm{OH})$ dẫn đến thiếu cortisol kèm theo (hoăc không), thiếu hut aldosterone và tăng tiết androgen thượng thận [1]. Mức độ nặng của triệu chứng lâm sàng khác nhau và phụ thuốc vào hoạt độ $21-\mathrm{OH}$ còn lại [2]. Dưa trển biểu hiện lâm sàng, bênh được chia thành hai thể: thể nặng (thể cổ điển) và thể nhe hơn (không cổ điển). Thể cổ điển lại được chia ra thành thể cổ điển mất muối (MM) (salt wasting - SW) và nam hóa đơn thuần (NHĐT) (simple virilizing - SV) phản ánh mức độ thiếu hụt aldosterone [3],[4].
Tại thể không cổ điển, hoạt độ enzyme còn khoảng $20-50 \%$, do đó hormone cortisol và aldosterone sản xuất bởi vỏ thượng thận đã giúp ngăn ngừa các biểu hiện lâm sàng cẩn điều trị bằng liệu pháp thay thế glucocorticoid hoặc mineralocorticoid. Tuy nhiên hàm lượng hormone vẫn chưa đủ để ức chế thỏa đáng việc sản xuất quá mức $A C T H$, các tiền chất steroid sẽ chuyển sang tổng hợp androgen và gây tăng androgen trong máu [5]. Các triệu chứng sớm của thể không cổ điển ở trẻ em có thể bao gồm: lông mu sớm, các biểu hiện của tăng androgen, trứng cá, tăng chiều cao nhanh và/hoặc tuổi xương phát triển sớm, tăng trưởng chiều cao có thể kết thúc sớm gây hậu quả chiều cao cuối cùng thấp [6]. Các triệu chứng muộn hơn bao gồm: rậm lông (60-78\%), rối loạn kinh nguyệt $(55 \%)$, trứng cá $(33 \%)$ và vô sinh $(12 \%)$ [7]. Các triệu chứng này là hậu quả của tăng androgen ở tuần hoàn. Các triệu chứng kín đáo ở bệnh nhân nam thậm chí không có triệu chứng hoăc chỉ có nhiều trứng cá và/hoăc khó khăn về sinh sản .Bên cạnh triêu chứng lâm sàng của bệnh nhân, Nồng độ 17-OHP ở điều kiện cơ sở và sau kích thích ACTH là một tiêu chuẩn bổ sung cho chẩn đoán [2].

Gen CYP21A2 là gen quy định sự mã hóa enzyme 21-Hydroxylase, hoạt độ enzym còn lại của bênh nhân phư thuộc vào mức đô̂ năng nề của đốt biến. Muốn xác định được đột biến trên bệnh nhân cần áp dụng nhiều phương pháp xác định đột biến, trong đó đột biến điểm được xác định bẳng việc ứng dụng phương pháp giải trình tự gen. Việc xác định đột biến ở bệnh nhân TSTTBS có ý nghĩa quan trọng trong thiết lập chẩn đoán, đặc biệt với thể không cổ điển. Ngoài ra thông tin về di truyền sẽ có ý nghĩa trong tư vấn di truyền cũng như trong chẩn đoán trước sinh cho những người mang gen. Do vậy, đề tài được thực hiên với muc tiêu: Xác đinh đột biến gen CYP21A2 trên các bênh nhần tăng sản thượng thận bẩm sinh thể không cổ điển.

\section{II. ĐỐI TƯỢNG VÀ PHƯƠNG PHÁP NGHIÊN CỨU}

1. Đối tượng. 4 bênh nhân TSTTBS thể thiếu enzym 21-hydroxylase thể không cổ điển được chẩn đoán và điều trị tại Khoa Nội tiết Chuyển hóa-Di truyền, Bệnh viện Nhi Trung ương.

\section{Phương pháp}

2.1. Kỹ thuật tách chiết DNA. DNA được tách chiết từ bạch cầu máu ngoại vi theo quy trình phenol/chloroform. Tất cả các mẫu DNA sẽ được tiến hành đo nồng độ và độ tinh sạch, chỉ có mẫu DNA đạt giá trị $\geq 1,8$ mói đạt yêu cầu về tinh sạch và được sử dụng để phân tích. 
2.2 Kỹ thuật giải trình tự gen. Toàn bộ chiều dài gen CYP21A2 được khuếch đại bằng phản ứng PCR với các cặp mồi đặc hiệu.

- Thành phần phản ứng: thế tích $20 \mu \mathrm{l}$ gồm: 100 - $150 \mathrm{ng}$ DNA, 5 pmol primer, $200 \mu \mathrm{mol} / \mathrm{l}$ dNTP, 2 đơn vị enzym Taq polymerase và $2 \mu \mathrm{l}$ GeneAmp $10 \times$ buffer.

- Chu trình nhiệt: $94^{\circ} \mathrm{C} / 5$ phút, $\left[94^{\circ} \mathrm{C} / 1\right.$ phút, $60^{\circ} \mathrm{C} / 1$ phút, $72^{\circ} \mathrm{C} / 1$ phút] $\mathrm{x} 35$ chu kỳ, $72^{\circ} \mathrm{C} / 2$ phút, giữ ở $15^{\circ} \mathrm{C}$. Sản phẩm PCR được điện di trên gel agarose $1 \%$, 90V trong 30 phút.

- Sản phẩm PCR sau khi điện di trên gel agarose được tinh sạch bằng Gel purification Kit trước khi tiến hành giải trình tự gen. Để giải trình tự được toàn bộ gen CYP21A2, sử dụng các mồi như đã mô tả ở bảng 2.1. Quy trình được thực hiện theo phương pháp BigDye terminator sequencing (Applied Biosystems, Foster city, USA).

Kết quả giải trình tự gen được phân tích bằng phần mềm CLC Main Workbench. Mẫu DNA của bệnh nhân được so sánh với mẫu DNA đối chứng và trình tự của CYP21A2 trên GeneBank (Accession number NM_0005002).

2.3 Kỹ thuật MLPA. Sử dụng kit MLPA P050B2 (MRC- Holland) để phát hiện đột biến xóa đoạn trên bệnh nhân và người lành mang gen bệnh. Thành phần của kit gồm các đầu dò (probe) để khuyếch đại gen CYP21A2, mỗi đầu dò tương ứng với một vùng gen, ngoài ra còn có các đầu dò đặc trưng cho gen của người cũng được sử dụng để làm đối chứng và 2 đâu dò cho nhiễm sắc thể $X$ và $Y$ để xác định giới tính. Sản phẩm khuếch đại sẽ được điện di mao quản trên máy giải trình tự. Số lượng sản phẩm khuếch đại của mỗi đầu dò sẽ tỷ lệ thuận với số bản copy của đoạn DNA đích đặc hiệu với đầu dò đó.

3. Đạo đức nghiên cứu trong $Y$ học. Nghiên cứu tuân thủ tuyệt đối các quy định về đạo đức trong nghiên cứu y sinh. Bệnh nhân hoàn toàn tự nguyện tham gia vào nghiên cứu. Bệnh nhân hoàn toàn có quyền rút lui khỏi nghiên cứu khi không đồng ý tiếp tục tham gia vào nghiên cứu. Bệnh nhân sẽ được thông báo về kết quả xét nghiệm gen để giúp cho các bác sỹ tư vấn di truyên hoặc lựa chọn phác đồ điều trị phù hợp. Các thông tin cá nhân sẽ được đảm bảo bí mật.

\section{KẾT QUẢ NGHIÊN CỨU}

Bảng 1 mô tả đặc điểm của 4 bệnh nhân thể không cổ điển trong đó có 3 bệnh nhân nam và 1 bệnh nhân nữ. Điện giải đồ ( $\mathrm{Na}, \mathrm{K}, \mathrm{Cl})$ của các bệnh nhân đều nằm trong giới hạn bình thường, 17-OHP tăng nhẹ.

Bảng 1. Đặc điểm lâm sàng và cận lâm sàng các bệnh nhân thể không cổ điển

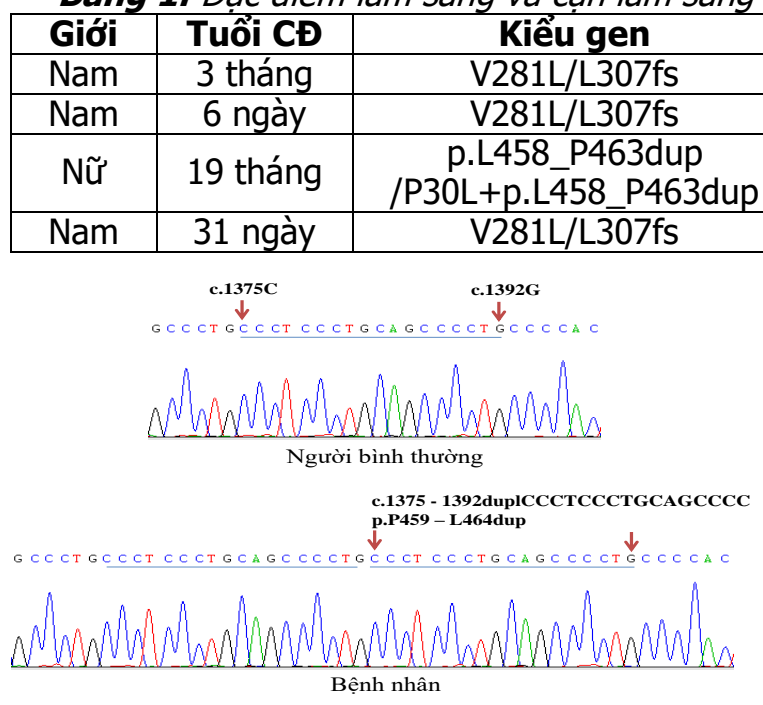

\section{Hình 1. Hình ảnh đột biến lặp đoạn} p.P459_L464dup

Hình 1 là kết quả giải trình tự gen CYP21A2 phát hiện bệnh nhân có đột biến lặp đoạn tại vị trí nucleotid từ 1375-1392 (CCCTCCCTGCAGCCCC). Hậu quả dẫn đến việc lặp lại đoạn 5 acid amin từ vị trí 459 cho đến 464 trên chuối acid a min của enzym 21 -Hydroxylase.

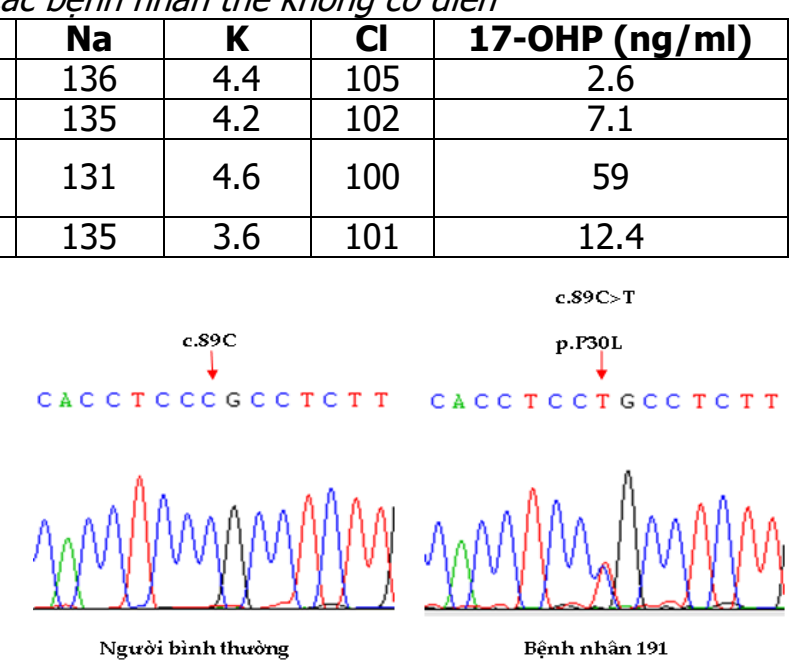

Hình 2. Hình ảnh đột biến sai nghĩa p.P30L

Hình 2 là hình ảnh giải trình tự của bệnh nhân mang đột biến sai nghĩa $C>T$ tại vị trí 89 trên trình tự c.DNA. Đột biến này làm thay đổi bộ ba mã hóa tại vị trí 30 trên trình tự acid amin từ Prolin chuyển thành Leucin. Đây là đột biến thuộc nhóm $C$, kiểu hình dự báo của đột biến là thể không cổ điển. 
Bằng phương pháp Giải trình tự gen và kỹ thuật MLPA, chúng tôi phát hiện cả 4 bệnh nhân có biểu hiện lâm sàng của thể cổ điển đều có đột biến gen CYP21A2. Trong đó 75\% bệnh nhân (3 trong 4 bệnh nhân) có kiểu gen p.V281L/p.L307FfsX6. Phân tích đột biến trên bệnh nhân còn lại cho kiểu gen: p.P30L+p.P459_L464dup/p.P459_L464dup. Đột biến lặp đoạn này là một đột biến mới chưa được công bố trên bất kỳ cơ sở dữ liệu hay nghiên cứu nào trên thế giới.

3 bệnh nhân có kiểu gen p.V281L/ p.L307FfsX6 đều có kiểu hình nam, nhưng chỉ 2 trong 3 bệnh nhân có triệu chứng xạm da vùng sinh duc.

Hình 3. Kiểu hình của bệnh nhân nữ số 191 mắc thể không cổ điển có mang alen đột biến p.P30L và một allele đột biến mới lặp đoạn (p.P459_L464dup/p.P30L+p.P459_L464dup).

Bệnh nhân với kiểu gen P30L+ p.P459 _L464dup/p.P459_L464dup là bệnh nhân nữ duy nhất trong 4 bệnh nhân thể không cổ điển. Bệnh nhân được chẩn đoán lúc 19 tháng tuổi, có kiểu hình nam hóa nhe (Prader II), tuối xương tương đương tuổi thực, điện giải đồ huyết thanh bình thường ( $\mathrm{Na} \mathrm{131;} \mathrm{K} \mathrm{4,6;} \mathrm{Cl} 100$ mmol/l); nồng độ 17-OHP huyết thanh tăng nhẹ $(59 \mathrm{ng} / \mathrm{ml})$.

\section{BÀN LUÂN}

Trong nghiên cứu này, 3 trong 4 bệnh nhân đều là trẻ trai và đều có kiểu gen là p.V281L/p.L307FfsX6. Cả 3 trẻ này đều được chẩn đoán nhờ sàng lọc các trẻ trai có xạm da vùng bìu. Nghiên cứu của New MI và cộng sự trên cõ mẫu rất lớn là 1545 bệnh nhân thể không cổ điển thì kiểu gen phổ biến nhất là p.V281L/p.V281L (38,5\%); I2g/p.V281L (19,8\%) và $\mathrm{Del} / \mathrm{p} . \mathrm{V} 281 \mathrm{~L}(17,4 \%)$ [8]. Mô hình dự báo cho thấy đột biến p.V281L gây giảm hoạt độ enzym một phần do sự bất thường cấu trúc không giann xảy ra khi valine được thay thế bởi leucine dẫn đến tăng chiều dài chuỗi polypeptide. Tuy nhiên, nghiên cứu trên 506 bệnh nhân có mang ít nhất 1 alen đột biến là p.V281L thì có 497 bệnh nhân $(98,2 \%)$ là có kiểu hình lâm sàng thể không cổ điển nhưng cũng có 3 bệnh nhân $(0,6 \%)$ mắc thể NHĐT thậm chí có 6 bệnh nhân $(1,2 \%)$ là mắc thể mất muối [6]. Các tác giả nhận định rằng tương quan kiểu gen - kiểu hình hay tương quan giữa cấu trúc protein đột biến và kiểu hình ở bệnh nhân TSTTBS không luôn luôn đúng.

Bệnh nhân nữ duy nhất mắc thể không cổ điển trong nghiên cứu này có kiểu gen p.P30L+L458_P463dup/L458_P463dup và kiểu hình nam hóa nhẹ (Prader II - Hình 1). Nghiên cứu của De Carvalho và cộng sự (2016) trên cõ mẫu lớn gồm 206 bệnh nhân thể không cổ điển cho kết quả tỷ lệ nữ/nam là $6,7 / 1,0$ và có tới $8 \%$ bệnh nhân nữ được chẩn đoán có phì đại nhẹ âm vật (Prader I). Kiểu gen có đột biến p.P30L thường được nhận thấy ở kiểu hình thể không cổ điển vì đột biến này chỉ gây mất $40-70 \%$ hoạt độ enzym qua nghiên cứu in vitro [9]. Điều này cũng được nhận thấy trong nghiên cứu này ở 1 bệnh nhẩn nữ mang đột biến p.P30L kết hợp với đột biến lặp đoạn mới (Hình 1). Tuy nhiên, nghiên cứu trên nhóm bệnh nhân đa chủng tộc có tới 23/74 (31\%) bệnh nhân mang đột biến p.P30L có kiểu hình là thể cổ điển. Theo dõ̃i diễn biến lâm sàng sau 2 đến 12 năm nhận thây diễn biến bệnh phù hợp với thể không cổ điển thiếu 21-OH. Nghiên cứu của Gidlof $S$ và cộng sự (2013) trên các bệnh nhân TSTTBS người Thụy Điển cũng xác định được 38 trẻ bú me mắc thể không cổ điển thiếu 21-OH, trong đó 24 trẻ không phát hiện được qua sàng lọc sơ sinh và chỉ 14 trẻ (37\%) có kết quả sàng lọc sơ sinh dương tính.

Trong nghiên cứu này, 4 bệnh nhân TSTTBS thể không cổ điển đã được đánh giá đặc điểm lâm sàng và phân tịch gen, do bệnh nhân thể không cổ điển được phát hiện với tỉ lệ khá thấp ở Việt Nam. Nguyên nhân chủ yếu có thể do triệu chứng của thể không cổ điển không rõ ràng và không biểu hiện sớm ở tất cả các bệnh nhân. Do đó ít gia đình và bệnh nhân tìm đến các cơ sở y tế để thăm khám. Ngoài ra, hiện nay, để chẩn đoán thể không cổ điển, bên cạnh triệu chứng lâm sàng, bệnh nhân cần được xác định nồng độ 17-OHP ở điều kiện cơ sở và sau kích thích ACTH, đồng thời thực hiện xét nghiệm di truyền để phát hiện đột biến gen. Đây đều là các kỹ thuật hiện đại chủ yếu được thực hiện tại các bệnh viện tuyến trung ương mà chưa được áp dụng tại địa phương, do vậy một số ca không cổ điển có thể bị bỏ sót.

\section{KẾT LUÂ̂N}

Bằng việc áp dụng các kỹ thuật phân tích đột biến trên 4 bệnh nhân TSTTBS thể không cổ 
điển, kết quả phát hiện cả 4 bệnh nhân đều có đột biến gen CYP21A2. Trong đó, 75\% bệnh nhân (3 trong 4) đều là nam và có kiểu gen p.V281L/p.L307FfsX6. Bênh nhân còn lại là bệnh nhân nữ duy nhất, có kiểu gen: p.P30L + p.P459_L464dup/p.P459_L464dup, đây là một đột biến mới chưa từng được công bố trên bất kỳ cơ sở dữ liệu hay nghiên cứu nào trên thế giới.

Lời cám ơn. Nghiên cứu được thực hiện sự giúp đỡ của các cán bộ của Trung tâm nghiên cứu Gen- Protein, Bộ mổn Nhi, Trường Đại học Y Hà Nội; Khoa Nội tiết-Chuyển hóa- Di truyền, Bệnh viện Nhi Trung ương.

TÀI LIỆ THAM KHẢO

1. Merke D.P. và Bornstein S.R. (2005). Congenital adrenal hyperplasia. The Lancet, 365(9477), 2125-2136.

2. Gonçalves J., Friães A., và Moura L. (2007). Congenital adrenal hyperplasia: focus on the molecular basis of 21-hydroxylase deficiency. Expert Rev Mol Med, 9(11), 1-23.

3. Krone N., Braun A., Roscher A.A. và cộng sự. (2000). Predicting phenotype in steroid 21- hydroxylase deficiency? Comprehensive genotyping in 155 unrelated, well defined patients from southern Germany. J Clin Endocrinol Metab, 85(3), 1059-1065.

4. New M.I. (2003). Inborn errors of adrenal steroidogenesis. Mol Cell Endocrinol, 211(1-2), 75-84.

5. New M.I. (1998). Diagnosis and Management of Congenital Adrenal Hyperplasia. Annu Rev Med, 49(1), 311-328.

6. Speiser P.W. và White P.C. (2003). Congenital Adrenal Hyperplasia. N Engl J Med, 349(8), 776-788.

7. Speiser P.W., Azziz R., Baskin L.S. và cộng sứ. (2010). Congenital Adrenal Hyperplasia Due to Steroid 21-Hydroxylase Deficiency: An Endocrine Society Clinical Practice Guideline. J Clin Endocrinol Metab, 95(9), 4133-4160.

8. New M.I., Abraham M., Gonzalez B. và cộng sứ. (2013). Genotype-phenotype correlation in 1,507 families with congenital adrenal hyperplasia owing to 21-hydroxylase deficiency. Proc Natl Acad Sci U S A, 110(7), 2611-2616.

9. Ogilvie C.M., Crouch N.S., Rumsby G. và cộng sự. (2006). Congenital adrenal hyperplasia in adults: a review of medical, surgical and psychological issues. Clin Endocrinol (Oxf), 64(1), 2-11.

\section{TÁC DỤNG CỦA CỦA TÂPP YOGA LÊN HUYẾT ÁP VÀ MộT Số CHİ Số NHÂN TRẮC Ở BỆNH NHÂN TĂNG HUYẾT ÁP NGUYÊN PHÁT Độ 1}

\section{TÓM TẮT}

Điều trị THA bên cạnh dùng các loại thuốc hạ huyết áp thì vấn đề thay đổi lối sống cũng góp phần quan trọng trong việc kiểm soát trị số huyết áp của bệnh nhân. Yoga giúp giảm huyết áp thông qua giảm cắng thẳng, giảm cholesterol máu và tăng độ đàn hồi của thành mach. Để góp phần cung cấp cở sở khoa học cho người bị cao huyết áp kiểm soát thông qua tập luyện Yoga, chúng tôi tiến hành đề tài này. Mục tiệu: (1) Đánh giá tác dụng của tập Yoga trong việc kiểm soát huyết áp ở bệnh nhân tằng huyết áp độ 1 và (2) Đánh giá tác dụng của tập Yoga lên một số chỉ số nhân trắc ở bệnh nhân tăng huyết áp độ I. Đối tượng nghiên cứu: Bệnh nhân THA nguyên phát độ 1 theo tiểu chuẩn chẩn đoán của WHO/ISH 2004, tuổi từ 30 đến 60 tuổi, hiện tại không dùng thuốc điều trị THA và các thuốc ảnh hưởng đến các chỉ số nghiên cứu. Thiết kế nghiên cứu: Nghiên cứu can thiệp có đối chứng. Kết quả: Tập Yoga làm giảm có ý nghĩa thống kê các chỉ số huyểt áp tâm thu và huyết áp tâm

*Đại hoc Y khoa Vinh

**Đai Hoc Vinh

Chịu trách nhiệm chính: Nguyễn Văn Tuấn

Email: tuanminh1976@gmail.com

Ngày nhận bài: 18.2.2021

Ngày phản biên khoa học: 26.3.2021

Ngày duyệt bài: 5.4 .2021
Nguyễn Văn Tuấn*, Hoàng Thị Ái Khuê** trương ở bệnh nhân tăng huyết áp độ 1 so với không tập Yoga. Tập Yoga cũng làm giảm có ý nghĩa thống kề chỉ số BMI, vòng bung và bề dày lớp mõ̃ dưới da ỡ bệnh nhân tăng huyết áp độ 1 so với không tập Yoga.

Tư khóa: Yoga, tăng huyết áp độ 1

\section{SUMMARY}

THE EFFECT OF YOGA ON BLOOD

PRESSURE CONTROL AND SOME ANTHROPOMETRIC INDEXS IN PATIENTS WITH GRADE 1 OF HYPERTENSION

Lifestyle changes are an important issue in treating high blood pressure. Yoga lowers blood pressure by reducing stress, lowering cholesterol and increasing the elasticity of the arteries. We conducted this study to provide a scientific basis for the treatment of hypertension of Yoga. Objectives: (1) Evaluate the effect of Yoga on blood pressure control in patients with grade 1 hypertension and (2) Evaluate the effects of yoga on some anthropometric indexs in patients with grade 1 hypertension. Study subjects: patients with primary grade 1 hypertension according to diagnostic criteria of WHO / ISH 2004, aged 30 to 60 years, currently do not take THA drugs and drugs that affect the study index. Study design: Intervention research. Result: Yoga significantly reduced systolic blood pressure and diastolic blood pressure in patients with grade 1 hypertension compared to non-yoga patients. Yoga also significantly reduced the BMI, 